\title{
UPDATED COUNTY MOSQUITO SPECIES RECORDS FOR NORTHWEST FLORIDA
}

\author{
JOHN P. SMITH ${ }^{1,2,3}$, TAYLOR J. TAYLOR ${ }^{1,4}$, CAMI I. ADAMS ${ }^{1,5}$, \\ RICHARD A. TENNANT, JR. ${ }^{1,2,6}$, ERIC COPE ${ }^{2,7}, \mathrm{JIMMY} \mathrm{WALSH}^{2}$, \\ BEN NOMANN', CALEB HORN', FRED JOHNSON', GAIL HILSON', \\ CHARLES GOLDEN', GARY O'NEAL', JOHN KOZAK', \\ KEITH ARMSTRONG ${ }^{2}$, AND LES CONYERS'
}

'Florida State University, 4750 Collegiate Drive, Panama City, FL 32405

${ }^{2}$ Florida A\&M University, John A. Mulrennan Sr., Public Health Entomology

Research and Education Center, 4000 Frankford Av., Panama City, FL 32405

${ }^{3}$ Current address and to whom correspondence should be addressed:

Public Health Entomology Services, LLC,

8205 Grand Palm Blvd., Panama City Beach, Florida 32408

${ }^{4}$ Current address: Pasco County Mosquito Control District, 2308 Marathon Rd., Odessa, FL 33556

${ }^{5}$ Current address: South Walton County Mosquito Control District, 774 N. County Hwy 393, Santa Rosa Beach, FL 32459

${ }^{6}$ Current address: Mosquito Surveillance Services, LLC, 100 Dogwood Lane, Crestview, FL 32536

${ }^{7}$ Current address: Bay County Mosquito Control, 4800 Fire Tower Rd, Panama City, FL 32404

Guest Editor: Nathan D. Burkett-Cadena

\begin{abstract}
This report updates the mosquito species composition for Santa Rosa, Okaloosa, Walton, Holmes, Washington, Jackson, Calhoun, Liberty, Gadsden, Leon, Wakulla, Jefferson, Madison, and Taylor Counties, through collections made in a centralized surveillance program operated from 2002-2020 in northwest Florida. 91 county species records were documented. The most notable discoveries included finding Mansonia titillans (Walker) in eleven of the fourteen surveyed counties, Psorophora horrida (Dyar and Knab) in nine, Anopheles perplexens Ludlow in eight and Culex erraticus (Dyar and Knab) and Uranotaenia lowii Theobald in seven. Psorophora mathesoni Belkin and Heinemann and Aedes japonicus japonicus (Theobald) were found in six new counties. Culex pilosus (Dyar and Knab) was found solely in Calhoun and Liberty Cos., while Culex peccator Dyar and Knab and Culex tarsalis Coquillett were recovered in Calhoun Co. and Santa Rosa Co., respectively. Mansonia titillans, Cx. erraticus, Cx. tarsalis and Ae. j. japonicus are known arbovirus vectors, thus increasing the disease risk in this region.
\end{abstract}

Key Words: mosquitoes, surveillance, species composition, distribution, northwest Florida

\section{INTRODUCTION}

County-level mosquito species distributions in Florida have been published by
Darsie and Morris (2003). Since then, several new introductions and county range expansions have been reported. Anopheles grabhammi (Theobald) and Aedes condoles- 
cens (Dyar and Knab) were discovered in Monroe County (Darsie et al. 2002 and Darsie 2003). Culex declarator Dyar and Knab was found in Indian River and Monroe Counties (Darsie and Shroyer, 2004). In northwest Florida, Culex coronator Dyar and Knab was originally discovered in Okaloosa, Santa Rosa, Washington and Walton Counties and later recovered in Bay and Holmes Counties (Smith et al. 2006, and Smith 2008). Additional surveillance found this species in all remaining Florida counties except Gulf, Franklin and Monroe Counties (Connelly et al. 2016). In 2009, collections of Culex erraticus (Dyar and Knab) were reported from Walton County (Vander Kellen et al. 2012). Aedes pertinex (Grabham) was discovered in 2011 in Indian River County (Shroyer et al. 2015) and Culex interrogator (Dyar and Knab) was originally found in Broward, Indian River, Okeechobee, and Citrus Counties (Shin et al. 2016). Aedes japonicus japonicus (Theobald) was first reported in a collection from Okaloosa Co. in 2012 and later in Bay, Leon, Santa Rosa and Walton Counties (Riles et al. 2017). Larvae and adults of the tropical mosquitoes Culex (Melanoconion) panocossa and Aedeomyia squamipennis (Lynch Arribalzaga) were discovered near Homestead, FL in Miami-Dade County (Blosser and Burkett-Cadena 2017, and Burkett-Cadena and Blosser 2017). This article documents additional records from surveillance conducted in 14 of 18 northwest Florida counties from 2002-2020.

\section{MATERIALS AND METHODS}

From 2002 through 2020, mosquito surveillance was conducted in Santa Rosa, Okaloosa, Walton, Holmes, Washington, Jackson, Calhoun, Liberty, Gadsden, Leon, Wakulla, Jefferson, Madison, and Taylor Counties in northwest Florida (Table 1). Mosquito Magnet X (MMX) traps a.k.a. "counterflow or pickle-jar traps" (Woodstream Corporation, Lancaster, PA) supplemented with $200 \mathrm{cc} /$ min. compressed carbon dioxide $\left(\mathrm{CO}_{2}\right)$ gas were operated year-round once per week during crepuscular and nocturnal hours to capture host-seeking mosquitoes at 12 sites per county except for Leon County. Leon County submitted collections from BG Sentinel traps (Biogents USA, Moorefield, WV) supplemented with octenol (Woodstream Corporation, Lancaster, PA), BG Lure (Biogents USA, Moorefield, WV), and dry ice at varying locations within the county.

Container-breeding mosquitoes were also surveyed by deploying one sixteenounce black ovicup (4imprint USA, Oshkosh, WI) supplied with red velour paper strip (Hygloss Products, Inc., Wallington, NJ 07057) or seed germination paper (Anchor Paper Co., St. Paul MN, 55101) at each MMX

Table 1. County, years, and funding source for mosquito surveillance.

\begin{tabular}{lll}
\hline \hline County & \multicolumn{1}{c}{ Years } & Funding Source \\
\hline Calhoun & \multicolumn{1}{c}{$2004,2015-2019$} & County and State \\
Gadsden & $2017-2020$ & County and State \\
Holmes & $2004,2015-2019$ & County and State \\
Jackson & $2004,2017-2019$ & County and State \\
Jefferson & $2017-2019$ & State \\
Leon & $2016-2020$ & County \\
Liberty & $2004,2015-2019$ & County and State \\
Madison & $2017-2019$ & State \\
Walton & $2002-2011$ & County \\
Okaloosa & $2002-2019$ & County \\
Santa Rosa & $2002-2020$ & County \\
Taylor & $2017-2019$ & State \\
Wakulla & $2015-2019$ & County and State \\
Washington & $2002-2007,2015,2017-2019$ & County and State
\end{tabular}


sites during 2017-18 in all counties except for Leon, Okaloosa, Santa Rosa, and Walton.

Adult mosquito traps were operated depending on available funding. The most intensive surveillance occurred 2017-2019 when the Florida Legislature funded the program through a Florida Department of Health (FDOH) - Florida State University (FSU) contract. The most consistent surveillance was in Santa Rosa and Okaloosa Counties where the program was continuously funded by the counties for 18 and 16 years, respectively. Other counties provided funding on an intermittent basis (Table 1). Santa Rosa, Gadsden, and Leon Cos. continued surveillance and/or identification services in 2020.

\section{RESULTS}

Ninety-one new county mosquito species records were documented from fourteen NW Florida counties (Tables 2 \& 3). Multiple collections of these species were made at several sites within each county. Table 3 provides collection details for specific sites with the most specimens collected. The greatest number of new county records were reported from Washington, Santa Rosa and Liberty Counties with sixteen, eleven, and ten, respectively. Okaloosa, Jefferson, and Calhoun Counties each had eight. The remaining counties ranged from one to seven new county records. Including these new records, the total known species for most counties ranged from 43-48. Based on our surveillance and review of the published literature for northwest Florida counties, Jackson and Leon Counties have the greatest known diversity with 57 and 53 species, respectively. The most notable observations in county range distributions included Mansonia titillans (Walker) in eleven of the fourteen surveyed counties, Psorophora horrida (Dyar and Knab) in nine, Anopheles perplexens Ludlow in eight and Cx. erraticus and Uranotaenia lowii Theobald in seven. Psorophora mathesoni Belkin and Heinemann and Ae. j. japonicus (Theobald) were found in six new counties. Culex pilosus (Dyar and Knab) was found solely in Calhoun and Liberty Cos., while Culex peccator Dyar and Knab and $\mathrm{Cu}$ lex tarsalis Coquillett were recovered in Calhoun Co. and Santa Rosa Co., respectively.

Ovitrap surveillance in Holmes, Washington, Jackson, Calhoun, Liberty, Gadsden, Wakulla, Jefferson, Madison, and Taylor Counties found only Aedes albopictus, Aedes triseriatus, and Ae. j. japonicus. Aedes aegypti was not collected in any of the surveyed northwest Florida counties by either adult traps or ovitraps.

\section{DISCUSSION}

In Florida, arboviruses that cause West Nile virus, Eastern equine encephalitis, and Venezuelan equine encephalitis, annually circulate among competent mosquito vectors and vertebrate reservoirs and are transmitted to humans and equine as dead-end hosts (Florida Department of Health 2019). This study documented in several northwest Florida counties the first occurrence of $M n$. titillans, Cx. erraticus, Ae. j. japonicus, and Cx. tarsalis that serve as vectors of these diseases. The first three species were found in $79 \%, 50 \%$, and $43 \%$ of the 14 counties surveyed. This is a significant expansion of the recorded county species composition, thus increasing our knowledge of the distribution of vectors and mosquito-borne disease in this region.

Some species collected in this surveillance program could be easily overlooked because of similarity to more commonly collected species. Culex tarsalis and Ps. horrida can be easily confused with $C x$. coronator and Ps. ferox, respectively. Connelly and O'Meara (2008) provide a helpful checklist of characteristics to aid in the identification of the Culex. Harrison and Whitt (1996) provide a similar checklist for the Psorophora.

Many of the species recovered in this program were likely present much earlier, but not detected due to the lack of surveillance throughout much of this region. More species could have been recovered by including additional surveillance methods beyond host-seeking adult traps and ovitraps such as: larval surveys, light trapping, resting box collections, and other adult aspiration methods. 


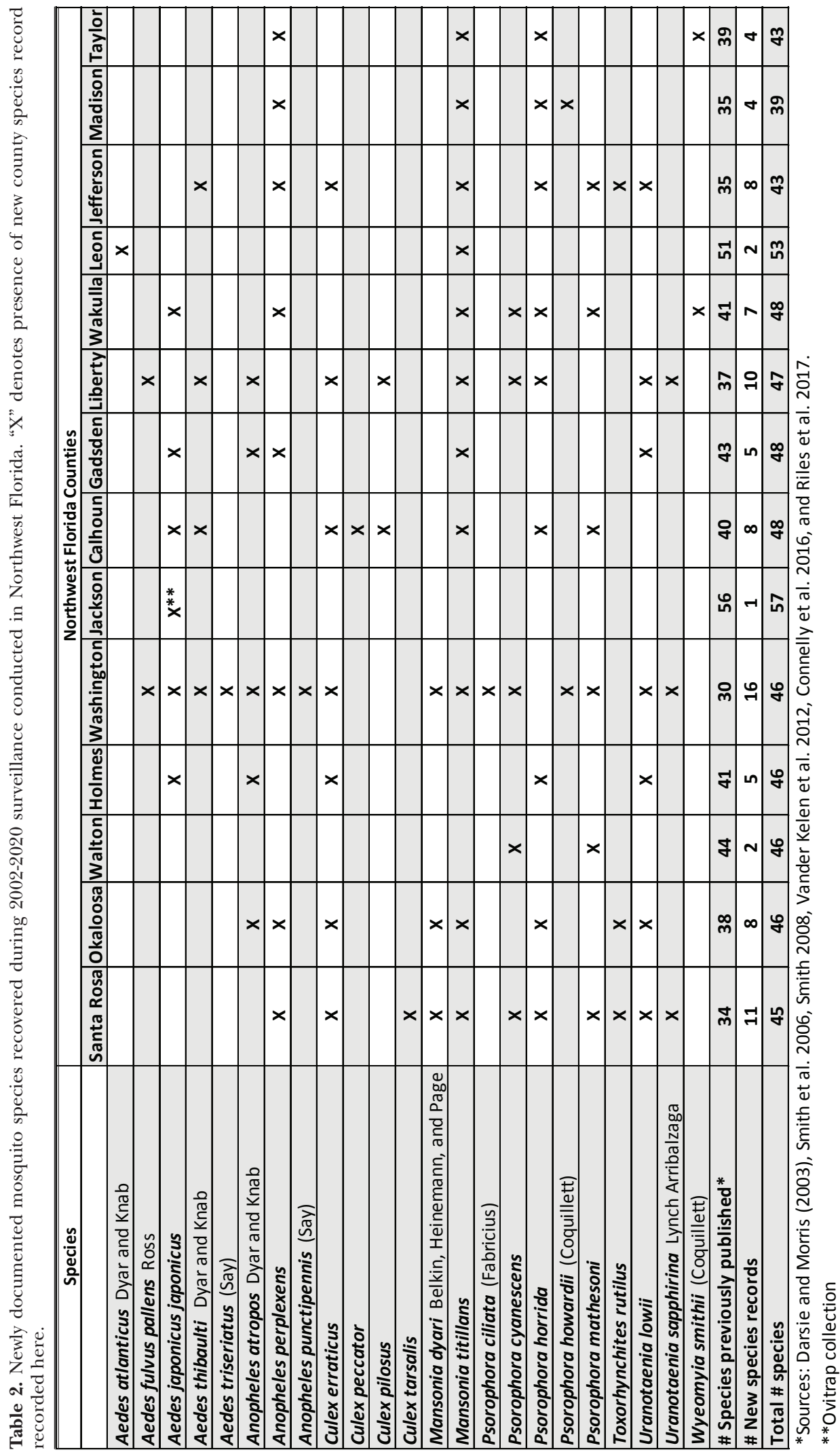




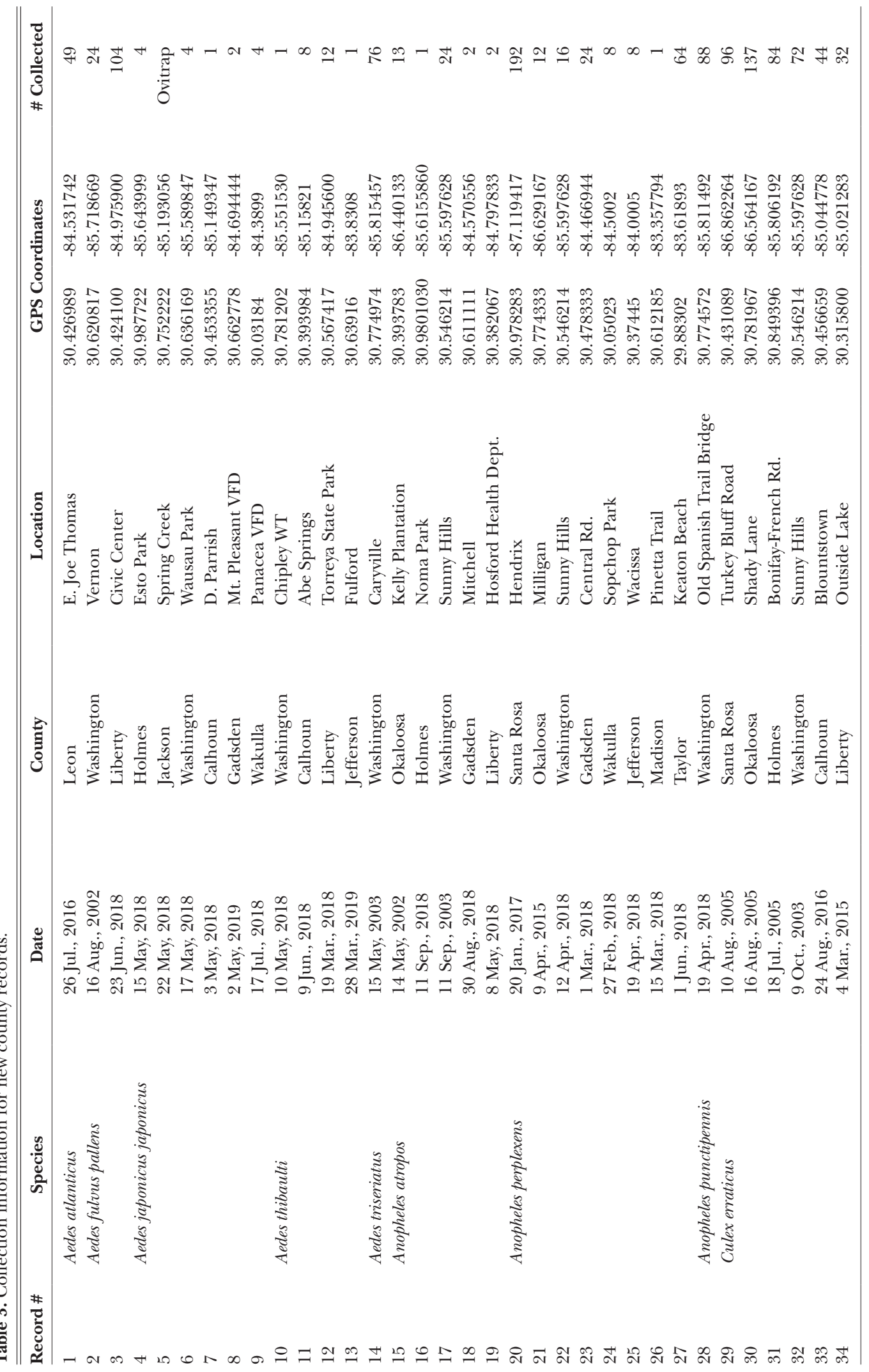




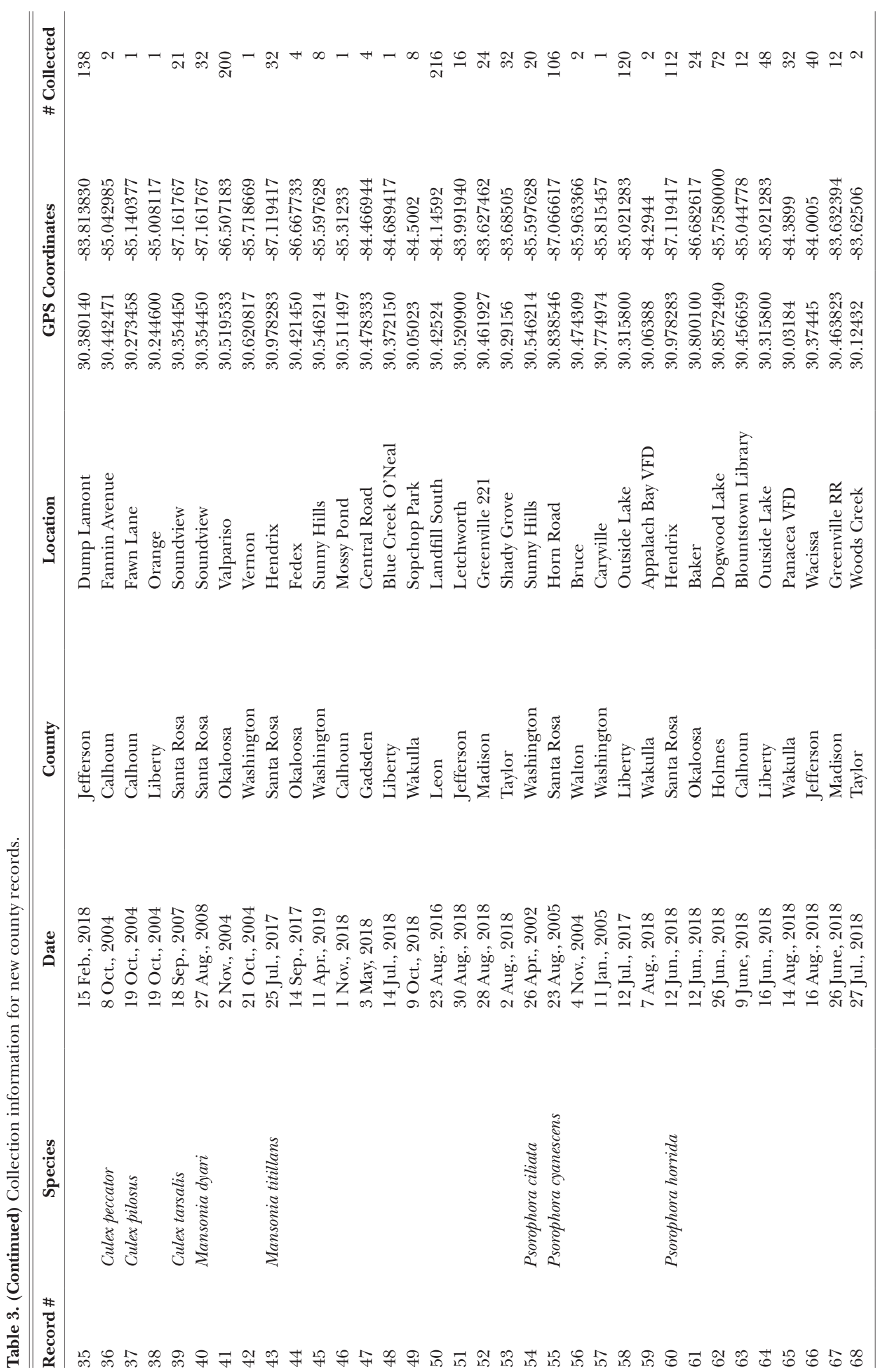




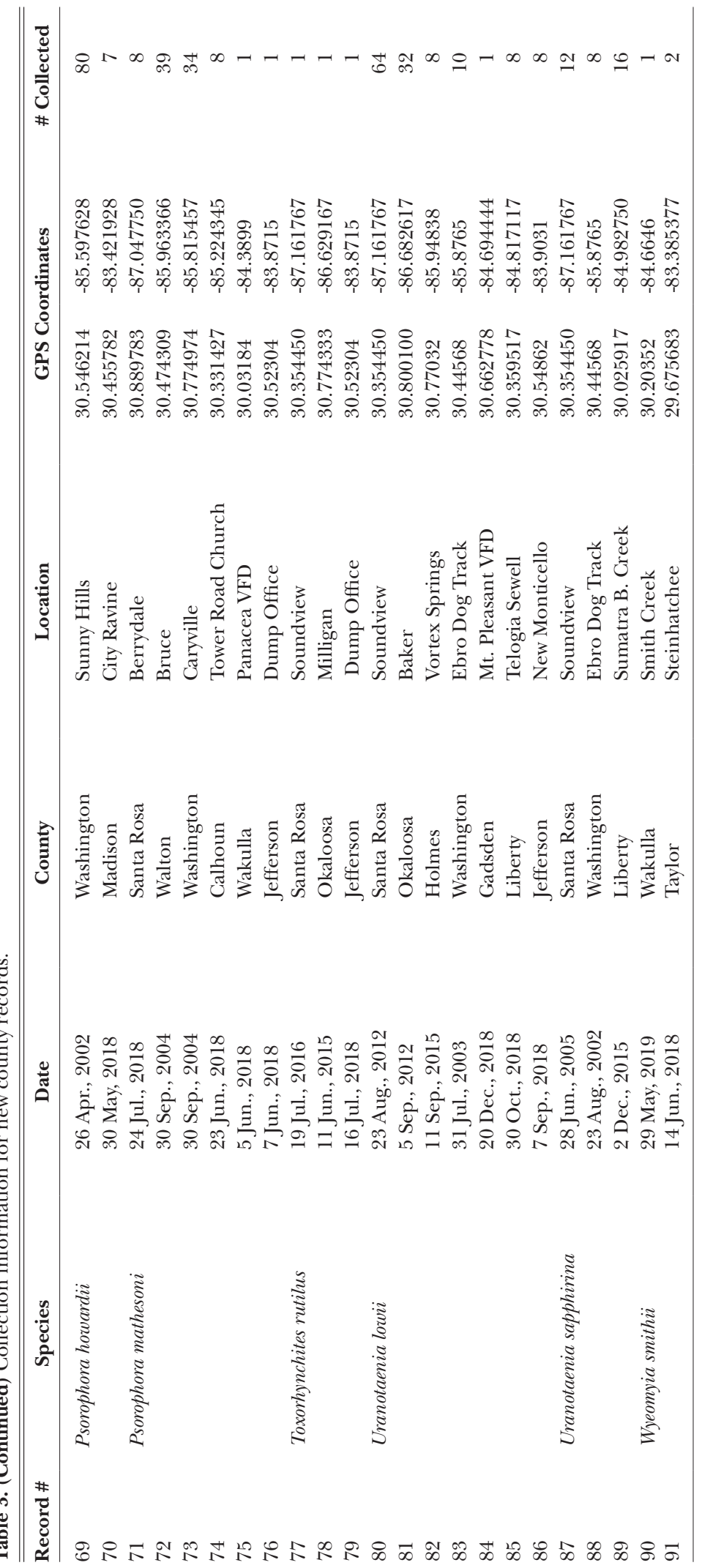


Mosquito surveillance is the foundation necessary for building and maintaining integrated mosquito control programs (EPA 2017). Rural counties that dominate most of northwest Florida do not have resources to provide surveillance without supplanting control operations. Faced with this choice, most forego or provide minimal surveillance. Determining species composition and quantifying population levels effectively aids in targeting/ prioritizing control efforts and assessing program efficacy. The welfare of Florida citizens and visitors would benefit greatly if sustained support for comprehensive surveillance was provided throughout the State.

\section{ACKNOWLEDGEMENTS}

This work was financially supported in part through FDOH contract \#CODNV made possible through appropriations from the Florida 2017 and 2018 Legislatures. It would not have been possible without the cooperation and support of the county mosquito control programs. The directors (listed below) and their staff greatly assisted in locating trap sites and providing needed information. Santa Rosa, Okaloosa, N. Walton, and Leon Cos. provided sole financial support for the surveillance program in their jurisdictions. Washington, Holmes, Liberty, Jackson, and Calhoun Cos. provided financial support in the intervening years before it was supported by FSU through the Florida Legislature. The state appropriations received in 2017 and 2018 were a huge boost to the ten most rural county programs. Dr. Randy Hanna, FSUPC Dean, and Kathy Mears, FSU Chief Legislative Affairs Officer, are recognized for supporting the FSU budget requests that made this possible. We also acknowledge the support of Banyon Pelham and the office staff in FSU-PC Contracts and Grants and the $\mathrm{FDOH}$ contract manager, Reneeka Rogers. We are indebted to the FSU-PC electrical engineering faculty, Drs. Geoffrey Brooks and Shafiul Islam, and their students who greatly assisted with trap hardware and software repairs and enhancements. Lastly, appreciation is extended to the reviewers of this manuscript who made helpful suggestions for improvements. The directors are: Parrish Barwick - Jefferson Co., David Brazille \& Lee Duke - Holmes Co., Al Cleveland \& Amanda Baker - Washington Co., Jace Ford - Calhoun \& Liberty Co., Stephen Ford - Liberty Co., Tommy Harkrider, Jr. - Jackson Co., Cindy Halsey \& Scott Henson - Okaloosa Co., Keith Hussey \& Tony Gomillion - Santa Rosa Co., Brenda Hunt N. Walton Co., Padraic Juarez-Wakulla Co., Glen Pourciau - Leon Co., Jamison Spencer - Gadsden Co., Cheryl White - Taylor Co., Jamie Willoughby - Madison Co.

\section{REFERENCES CITED}

Blosser EM, Burkett-Cadena ND. 2017. Culex (Melanoconion) panocossa from peninsular Florida, USA. Acta Trop 167: 59-63.

Burkett-Cadena ND and Blosser EM. 2017. Aedeomyia squamipennis (Diptera: Culicidae) in Florida, USA, a new state and county record. J Med Entomol 54: 788792.

Connelly CR, Alto BW, O'Meara GF. 2016. The spread of Culex coronator (Diptera: Culicidae) throughout Florida. J Vec Ecol 41: 195-199.

Connelly CR, O'Meara GF. 2008. Is it Culex tarsalis or Culex coronator? Buzz Words Sep/Oct.

Darsie RF Jr, Vlach JJ, and Fussell EM. 2002. New addition to the mosquito fauna of United States, Anopheles grabhamii (Diptera: Culicidae). J Med Entomol 39: 430-431.

Darsie RF Jr. 2003. First report of Ochlerotatus condolescens (Dyar and Knab) (Diptera: Culicidae) in the United States. Proc Entomol Soc Wash 105: 1067-1068.

Darsie RF Jr, Morris CD. 2003. Keys to the Adult Females and Fourth Instar Larvae of the Mosquitoes of Florida (Diptera: Culicidae). Tech Bull FL Mosq Control Assoc 1: 1-159.

Darsie RF Jr, Shroyer DA. 2004. Culex (Culex) declarator, a mosquito species new to Florida. J Am Mosq Control Assoc 20:224-227.

EPA. 2017. Success in Mosquito Control: An Integrated Approach. https://www.epa.gov/mosquitocontrol/ success-mosquito-control-integrated-approach

Florida Department of Health. 2019. Mosquito-Borne Disease Guidebook. Ch. 2. http:/ / www.floridahealth.gov/ diseases-and-conditions/mosquito-borne-diseases/ guidebook.html.

Harrison BA, Parker BW. 1996. Identifying Psorophora horrida females in North Carolina (Diptera: Culicidae). J Am Mosq Control Assoc 12:725-727.

Riles M, Smith JP, Burkett-Cadena ND, Rutledge-Connelly CR. 2017. First Record of Aedes japonicus In Florida. J Am Mosq Control Assoc 33:340-344.

Shin D, O’Meara GF, Civana A, Shroyer DA, Miqueli E. Culex interrogator (Diptera: Culicidae), a mosquito species new to Florida. J Vec Ecol 41:316-319.

Shroyer DA, Harrison BA, Bintz BJ, Wilson MR, Sither CB, Byrd BD. 2015. Aedes pertinax, a newly recognized mosquito species in the United States. $J$ Am Mosq Control Assoc 31: 97-100. 
Smith JP. 2008. Spread, larval habitat, seasonal abundance and vector status of Culex coronator. A new invasive vector species in Florida. Report to the FL Dept of Ag and Cons Srvs. http://www.freshfromflorida.com/content/download/3174/19965/Coronator\%20Final\%20FDACS\%20Report.pdf

Smith JP, Walsh JD, Cope EH, Tennant Jr. RA, Kozak III JA, and Darsie Jr. RF. 2006. Culex coronator Dyar and
Knab: a new Florida species record. J Am Mosq Control Assoc 22: 330-332.

Vander Kelen PT, Downs JA, Burkett-Cadena ND, Ottendorfer CL, Hill K, Sickerman S, Hernandez J, Jinright J, Hunt B, Lusk J, Hoover V, Armstrong K, Unnasch RS, Stark LM, and Unnasch TR. 2012. Habitat associations of Eastern Equine Encephalitis transmission in Walton County, Florida. J Med Entomol 49(3): 746-756. 